\title{
APPLICATION OF PSInSAR FOR ASSESSMENT OF SURFACE DEFORMATIONS IN POST-MINING AREA - CASE STUDY OF THE FORMER WALBRZYCH HARD COAL BASIN (SW POLAND)
}

\author{
Wojciech MILCZAREK * Jan BLACHOWSKI and Piotr GRZEMPOWSKI \\ Wroclaw University of Science and Technology, Faculty of Geoengineering, Mining and Geology, Na Grobli 15, 50-421 Wroclaw, Poland \\ *Corresponding author's e-mail: wojciech.milczarek@pwr.edu.pl
}

\section{ARTICLE INFO}

\section{Article history}

Received 17 May 2016

Accepted 16 August 2016

Available online 13 December 2016

Keywords:

PSInSAR

Secondary deformations

Coal mining

Former mining grounds

\section{ABSTRACT}

The study presents results of surface displacements calculated with the PSInSAR technique for the area of the former Wałbrzych Hard Coal Basin (WHCB) in SW Poland. Underground mining of hard coal took place there until the late 90 'ties of the $20^{\text {th }}$ Century. In accordance with the present state of knowledge, secondary deformations are a common phenomenon on post-mining areas. The chosen monitoring technique has provided data and has allowed study surface movements in Wałbrzych in the post mining period, for which no other, conventional surveys were available. In the analysis radar images acquired by the ENVISAT satellite for the 458 track and for the $2002-2009$ period have been used. The results of PSInSAR data processing indicate elevation of the surface within the boundaries of former mining areas, reaching up to $+6 \mathrm{~mm} / \mathrm{yr}$ and on average $+4 \mathrm{~mm} / \mathrm{yr}$. We assume that the end of mine water drainage and restoration of Carboniferous ground water table is the main factor responsible for this process and observe delayed response of the rock mass.

\section{INTRODUCTION}

Surface deformations of mining grounds are caused by disturbance of the natural rock mass balance by underground extraction of minerals. In the consequence of this, voids are created in the rock mass and the rocks surrounding the area of mining shift inwards to fill the empty space left in the place of extracted material. This causes changes of the natural stress conditions in the rock mass. Depending on the depth of mining continuous or discontinuous deformations develop at the surface. The first in the form of gentle depressions in the ground, the latter in the form of fissures, pits or escarpments. With the end of mining, this process gradually diminishes in time. Secondary deformations, i.e. surface movements in the time after the end of mining are usually associated with restoration of ground water levels that causes swelling and reduction of normal stresses in overlying rock layers (elevation) (Fenk, 1999) or the effect of the destruction of shallow underground workings (subsidence). Evidence presented in studies of postmining areas (Mathey, 2013; de Vent and Roest; 2013; Samsonov et al., 2013) show that substantial surface movements occur even many years after the end of mining and can be a threat to present day development and new use of post-mining areas.

In case of former mining areas, studies of present-day mining related deformations can be carried out based on data acquired directly from field surveys, i.e. precise levelling (Kuşcu, 1991; Blachowski et al., 2014; Blachowski et al., 2015) or satellite GPS measurements (Hejmanowski et al., 2008; Doležalová et al., 2009; Muntean et al., 2016). However, usually mining deformation surveys are not continued in the post-mining period and in a consequence it is impossible to determine the extent and size of ground surface displacements resulting from the processes occurring in the rock mass. In such cases SAR (Synthetic Aperture Radar) data acquired by satellites orbiting the Earth since the beginning of the 90 'ties of the $20^{\text {th }}$ Century can be used. With a suitably large number of radar images it is possible to determine surface displacements over large areas with millimeter accuracy (Ferretti et al., 2007).

The aim of this study has been to use the persistent scatterer satellite interferometry (PSInSAR) technique to determine surface movements in the area of the former Wałbrzych Hard Coal Mines in SW Poland and to analyse character of these movements in the post-mining period (2002-2009). It is the first study that covers the entire former mining area in Wałbrzych and provides information on the character of secondary movements there.

\section{DESCRIPTION OF THE STUDY AREA}

The area of former mining grounds in Wałbrzych extends between longitudes $16^{\circ} 7$ ' $10^{\prime \prime} \mathrm{E}$ and $16^{\circ} 20^{\prime} 34^{\prime \prime} \mathrm{E}$ and latitudes $50^{\circ} 42^{\prime} 25^{\prime \prime} \mathrm{N}$ and 
$50^{\circ} 47^{\prime} 50^{\prime} \mathrm{N}$ and covers approximately $94 \mathrm{sq} \mathrm{km}$ (Fig. 1). It is situated in the southern part of the Wałbrzych Mountains, in intra-mountainous depressions of the Central Sudety Mountains. The region has differentiated topography with wooded hills, Mt. Chelmiec (851 m a.s.1.) being the highest one, separated by elongated valleys. Coal mining in Wałbrzych lasted for several centuries and has caused transformations of the original topography such as development of subsidence basins and construction of anthropogenic forms of terrain e.g. settlement ponds and waste dumps. The latter, reaching up to $100 \mathrm{~m}$ above the ground, are sometimes larger in size than the neighbouring natural forms of the ground. Height differences of the surface reach up to $350 \mathrm{~m}$ (Fiszer et al., 1998).

The local geology is differentiated in terms of the continuity of deposits, thickness of deposited formations and tectonic conditions (Kożuchowicz and Oprychał, 1984). The Wałbrzych coal basin is of a limnic-type, where deposition of material took place in intra-mountainous sedimentary basins. This has resulted is a mixed exogenous - endogenous coal deposit (Kominowski, 2000). The coal-bearing layers are associated with three of the four lithostratigraphic Pennsylvanian complexes: the Žaclér formations, the Biały Kamień and the Wałbrzych formations. Altogether, 80 coal seams have been identified, including 48 in the Žaclér formations and 30 in the Wałbrzych formations. The stratal dips are towards the centre of the basin, ranging from several to over 30 degrees, and from 30 degrees to 60 degrees in the basin edges. The complicated geological structure is the results of intrusive and compressive tectonic activity of the Asturian phase. Most of the faults trend from NW towards SE with the influence of the Chelmiec intrusion clearly marked by longitudinal and latitudinal faults. The throw of the main faults reaches $300 \mathrm{~m}$. In addition, there are numerous local faults in the hard coal-bearing layers, with throws of several metres (Kominowski, 2000).

The beginning of coal mining in Wałbrzych dates back to the second half of the $14^{\text {th }}$ Century. At that time coal was mined from the surface. With the progress of time underground methods were introduced and coal production intensified. In the second half of the $19^{\text {th }}$ Century mining of coal from coal layers located under settlements and linear infrastructure (roads, railways, etc.) began. After World War II coal production peaked in 1955 with $3.25 \mathrm{~m}$ tonnes, later on the values oscillated around $2.5 \mathrm{~m}$ tonnes per year. Mining operation gradually diminished between 1993 and 1999. The steady drop in production of coal was accompanied by controlled flooding of underground workings through decrease in mining drainage of the rock mass. The process of mine flooding was started in 1994 and because of favourable geological settings particular coal fields could be flooded independently (Fiszer and Gogolewska, 2003).
It is estimated that the total subsidence of the ground surface for the entire period of mining has reached $-23 \mathrm{~m}$ (Kowalski and Jedrzejec, 2000). Since the end of mining operations in Wałbrzych comprehensive surveys of surface displacements on mining grounds have been stopped. Studies of secondary deformations in this area have been subsequently initiated by the Geodesy and Geoinformatics Department at the Wroclaw University of Science and Technology (Blachowski, 2008). The results of precise levelling measurements limited to several campaigns of selected parts of the existing geodetic network have been described in (Blachowski et al., 2010). These indicated height changes of eleven measured benchmarks in the range from $+128 \mathrm{~mm}$ to $+152 \mathrm{~mm}$ in the $2000-2008$ period. One benchmark has shown movement of $+408 \mathrm{~mm}$. In 2014 periodic (twice a year) surveys of a geodetic network covering $80 \mathrm{~km}$ of levelling lines and over 500 benchmarks were started (Milczarek, 2014).

\section{METHODOLOGY}

In this study surface deformation calculations based on the processing of PSInSAR (Persistent Scatterer SAR Interferometry) have been carried out. The PSInSAR technique is a development of the classical InSAR method, where two spatially convergent radar images covering the same area but acquired at different times are processed to generate digital elevation model (Zebker and Goldstein, 1986; Hanssen, 2001). The PSInSAR method was developed

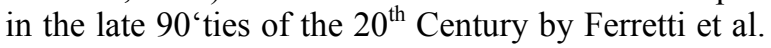
(2000; 2001). Detailed description of this processing procedure has been described in (Hooper et al., 2004; Hooper, 2006). The key stage in the method is the selection of stable scatterers, for which the components of the following equation can be determined (1):

$$
\Phi_{i, j}=\Phi_{d e f o, i, j}+\Phi_{\alpha, i, j}+\Phi_{o r b i t, i, j}+\Phi_{\varepsilon, i, j}+n_{i, j}
$$

$\Phi_{d e f o, i, j}$ - is the part of the signal phase representing ground surface movement in the satellite line-of-sight (LOS),

$\Phi_{\alpha, i, j}$ - is the component representing atmospheric retardation between passes (APS),

$\Phi_{\text {orbit }, i, j}{ }^{-}$is the phase component representing inaccuracy of the orbit,

$\Phi_{\varepsilon, i, j}$ - is the residual part of the phase resulting from the DEM error,

$n_{i, j}$ - is the remaining errors such as error of SAR images coregstration.

Two selection methods can be applied, one based on amplitude analysis using the dispersion of amplitude (Ferretti et al., 2001), the second based on temporal analysis of coherence coefficient (Hooper et al., 2004). The latter is effective for large values of signal to noise ratio and implemented in the 
STAMPS/MTI environment. It has been used for data processing and calculations in the presented research. The errors associated with heterogeneity of the atmosphere (i.e. Atmospheric Phase Screen) and temporal and geometric decorrelation of data can be eliminated through processing of a sufficiently large amount of radar images. Therefore, the method can be applied to study long-term changes (movements) of the ground surface. It has been successfully applied to investigate the influence of water reservoir exploitation (Chaussard et al., 2014; Raspini et al., 2014), volcanic activity (Hooper et al., 2004; Peltier et al., 2010), tectonic processes (Gourmelen et al., 2010; Hooper et al., 2012) and landslide monitoring (Perrone et al., 2013; Ciampalini et al., 2014). With respect to satellite interferometry applications in assessment of surface movements in post-mining areas and with respect to the presented study, the publications by (Cuenca et al., 2013; Samsonov et al., 2013; Lazecký and Jiránková, 2013) are noteworthy. Cuenca et al. (2013) have used the PSInSAR technique to assess surface activity in a former-mining Limburg coal region in the southern part of the Netherlands bordering with Germany and Belgium. The authors have used datasets acquired between 1992 and 2009 by the ERS $1 / 2$ and Envisat satellites to calculate surface deformations. Results of data processing have revealed elevation of the ground surface of up to $+220 \mathrm{~mm}$ in a period of 18 years. These movements have been correlated with hydrogeological data representing the process of underground water level restoration in the post-mining period. The study by Samsonov et al. (2013) concerned a novel processing of Small Baseline (SB) InSAR technique for the former mining area of the Greater Region of Luxembourg along the FrenchGerman border. The authors have identified secondary deformation based on the results of analyzing 167 radar images acquired between 1993 and 2011 from the ERS and Envisat satellites. Lazecký and Jiránková (2013) have applied PS and SB InSAR techniques for processing ERS-1, ERS-2 and Envisat datasets together with DInSAR processing of ALOS Palsar data with the aim to monitor ground movements in the area over the Karviná Mine Lazy plant in the Czech part of the Upper-Silesian Coal Basin. The results of processing satellite data have been compared with levelling measurements results. Other examples of satellite interferometry applications in assessing activity of mining and post-mining areas such as (Herrera et al., 2007; Jung et al., 2007; Jiang et al., 2011; Fan et al., 2014; Liu et al., 2014; Zhang et al., 2015; Bateson et al., 2015) indicate that the method has been widely applied to investigate mining related ground deformations.

\subsection{DATA AND SOFTWARE}

The following software have been used in the study, DORIS (Kampes et al., 2003) to generate interferograms from radar images, STAMPS/MTI
(Hooper et al., 2004) and Matlab for selection and further processing of the persistent scatterer (PS) dataset. In the calculations, the SRTM (Shuttle Radar Topography Mission) obtained from the U.S. Geological Survey, has been used at the stage of removing the topographical component.

The processed SAR data consisted of 21 Envisat satellite images from the 458 track (Table 1). The calculations covered approximately $350 \mathrm{sq} \mathrm{km}$ that included former mining grounds in Wałbrzych area and northern parts of the city outside the former mining areas. The radar image from 23-07-2004 has been chosen as the master scene (Fig. 2).

Table 1 SAR data information used in this study.

\begin{tabular}{l|c}
\hline Sensor & ENVISAT ASAR \\
Band & $\mathrm{C}$ \\
Wavelength $(\mathrm{mm})$ & 56 \\
Incidence angle $\left(^{\circ}\right)$ & 23.2 \\
Heading $\left(^{\circ}\right)$ & -168.2 \\
Track & 458 \\
Polarization & VV \\
Pass & Ascending \\
No. of images & 21 \\
Date range & $2002-2009$ \\
\hline
\end{tabular}

\section{RESULTS AND DISCUSSION}

The results of PSInSAR processing of radar images are a dataset of over 10000 permanent scatterer (PS) points. This equals to approximately 30 points per sq $\mathrm{km}$. However, the spatial distribution of PS points is irregular. This is caused by the topography of the area and location of buildings in Wałbrzych and neighbouring towns of BoguszówGorce and Szczawno-Zdrój. More PS points are located in these cities, which is caused by the fact that stable scatterers such as building roofs and other constructions that constitute potential PS points are located in urban areas. Permanent scatterers outside developed areas are identified in rock outcrops areas. The smaller number of stable scatterers outside urban areas is connected with the effect of vegetation in these latitudes. Based on the results of previous studies (Kowalski and Jędrzejec, 2000; Blachowski et al., 2010; Blachowski et al., 2015) it is known that mining related surface deformation in Walbrzych is associated with the valleys where most of land development took place and not the mountainous parts of the area. The density of identified PS in the developed areas is approx. 75 points/sq $\mathrm{km} \mathrm{(9508}$ points). These factors make the chosen technique suitable for studies of surface deformations.

Analysis of the distribution of PS points with registered significant positive (upward) movements (greater than $\pm 1 \mathrm{~mm} /$ year) shows that the majority of them are within the limits of the former mining areas in Wałbrzych. Significant upward movements (in Line 


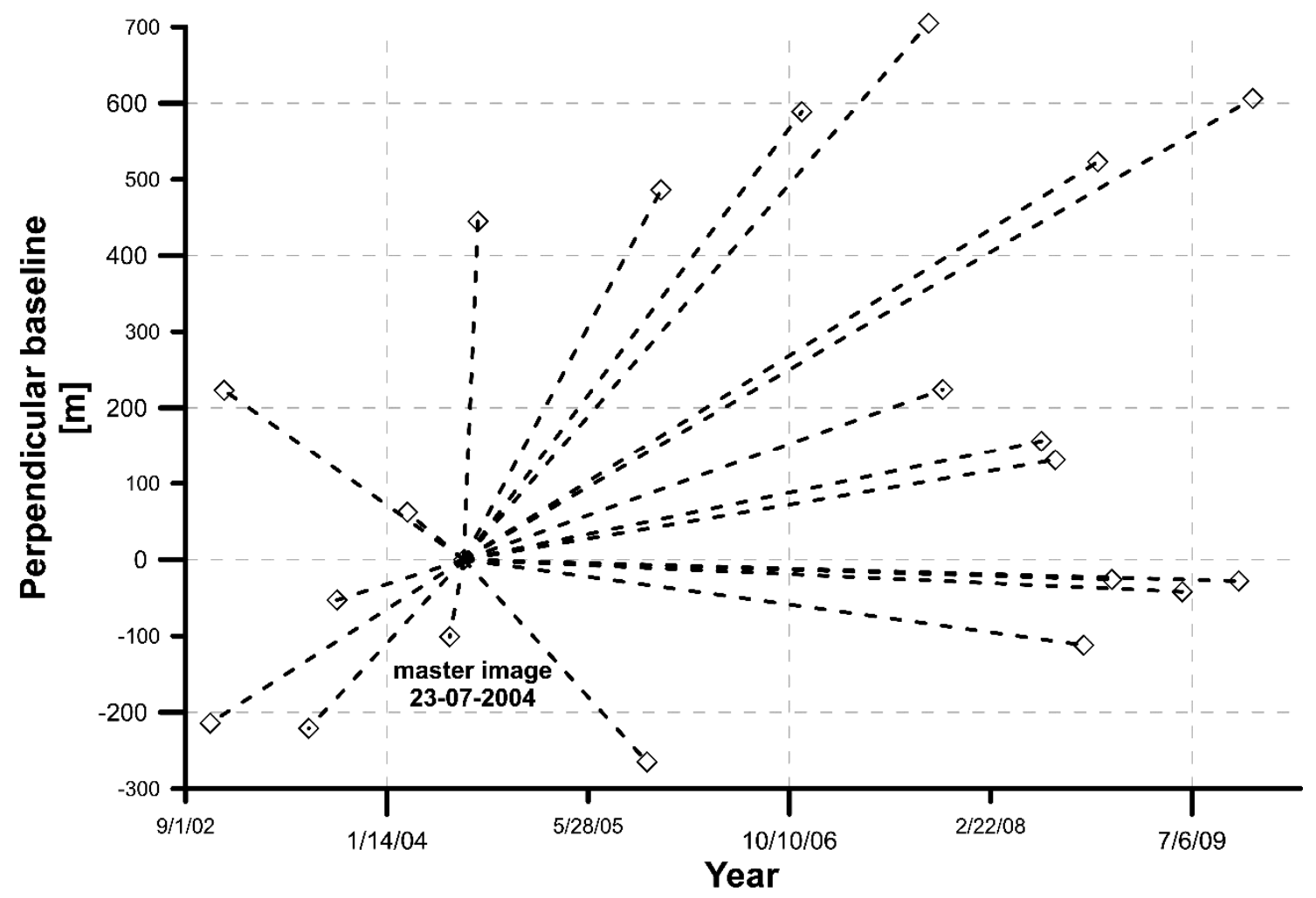

Fig. 2 Baseline information for the ENVISAT ASAR. The centre of the connecting lines is the master scene for the ENVISAT ASAR dataset. The image of 23-07-2004 was selected as the master image.

of Sight) are particularly visible in the central part and southern parts of the mining area. Figure 3 represents location of identified PS points (10 447), the numbers in square brackets indicate number of PS points in a given class. Figure 4 represents deformation surface generated with the spline interpolation method and calculated movements (in Line of Sight) of PS points as input. The spline surface has been optimized to minimize interpolation errors with the cross-validation technique. It gives a visually more coherent representation of deformations for the analysed period (2002-2009). Location of the selected 18 representative PS points discussed in detail in the following section is also marked in Figure 4. Field and aerial photos of two representative PS point locations (PS point no. 16 and PS point no. 18) have been shown in Figure 6.

The histogram in Figure 5 represents the distribution of average annual surface movements (in Line of Sight). The largest group is the PS points with average annual movements in the range from $-1.0 \mathrm{~mm}$ to $+1.0 \mathrm{~mm}$ (marked in grey). As mentioned these values are with the accuracy limits of the PSInSAR method (Ferretti et al., 2007). These points are located predominately in the northern and eastern parts of the study area, outside the area of former mining operations (Fig. 4). There are 2484 PS points with registered upward movement in the range from $+1.0 \mathrm{~mm}$ to $+6.0 \mathrm{~mm}$ annually that we consider significant (marked in blue). In addition 64 PS points show significant subsidence in the range from $-1.0 \mathrm{~mm}$ to $-6.0 \mathrm{~mm}$ per year (marked in red).

Figures 7 to 10 contain graphs of movements registered in the analysed period (2002-2009) on 18 selected, representative PS points. These points are characterized with the highest coherence and their displacement plots have the lowest $\Phi_{\varepsilon, i, j}$ error (vide equation (1)) values. Figure 7 shows graphs of displacements (LOS) for 5 PS points $(5,13,15,16$ and 18) located in the Julia-Pokoj former mining ground and underground water reservoir in the north. All the points there show upward movement of 25 to $30 \mathrm{~mm}$ in the analysed period (approx. $4.5 \mathrm{~mm} /$ year). Figure 8 contains graphs of displacements of 6 representative points $(1,2,3,4,8$, and 9) for the Victoria-Chrobry former mining ground in the centre of the analysed area. All the points there also demonstrate upward movement with points no. 3 and no. 4 registering the greatest displacement values reaching $40 \mathrm{~mm}$ (approx. $5.5 \mathrm{~mm} /$ year). For the points nos. 3, 4, 9 three different stages of movement can be distinguished: inactivity (lack of significant movements), dynamic upward movement and again lack of significant movements. Points nos. 1, 2, 8 have experienced change of the direction of displacement in the third phase (subsidence). In Figure 9 graphs of displacements of representative PS points (nos. 7, 14, 17) for the third area of Witold-Barbara in the south have been presented. Here, also two points nos. 14 and 17 indicate three stages of movement: inactivity, 


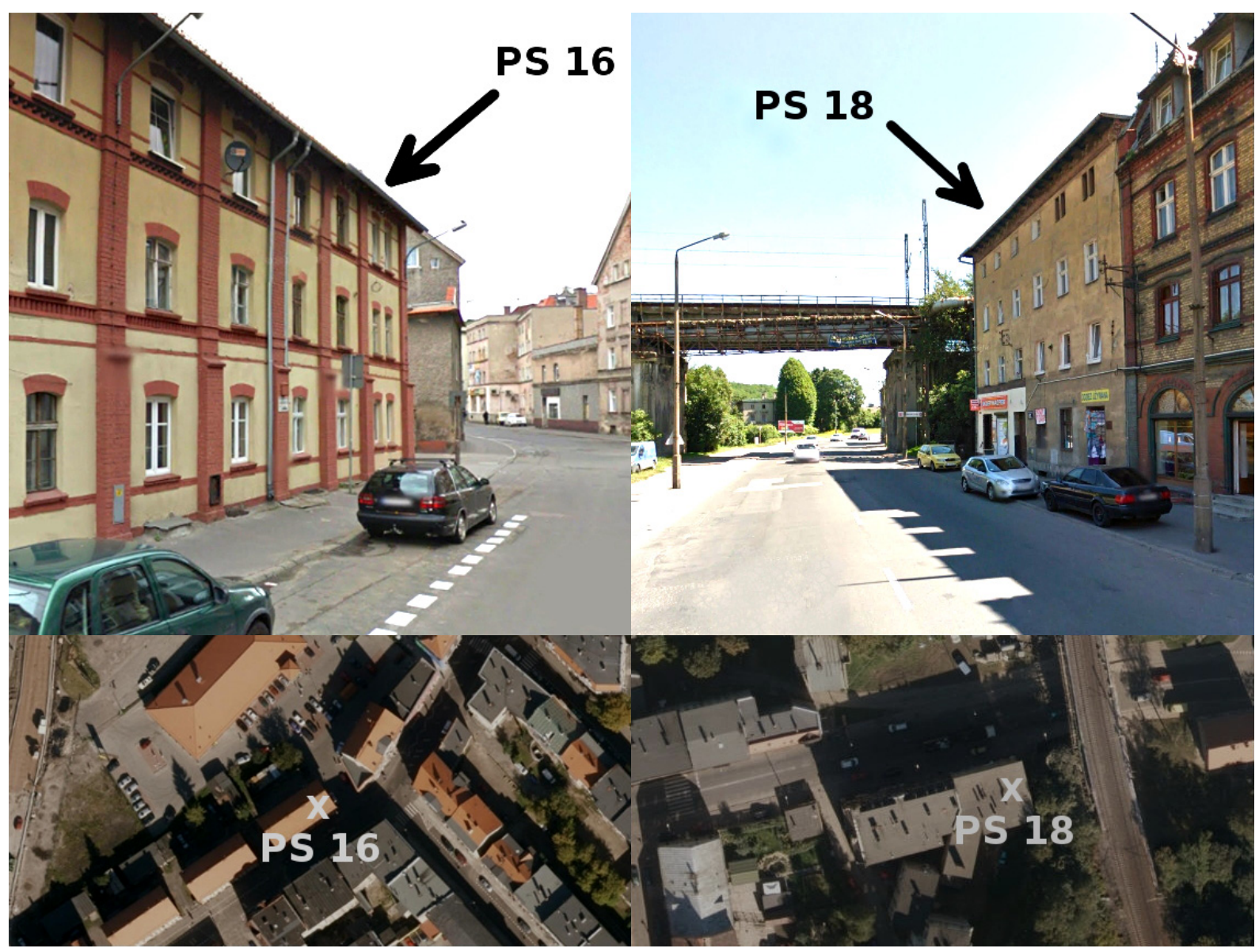

Fig. 6 Field and aerial photos of PS point no. 16 (left) and PS point no. 18 (right) (source of aerial images http://geoportal.dolnyslask.pl).

upward movement and again stagnation. Whereas point no. 7 shows indications of the latter two stages only. Movements in this area reach up to $25 \mathrm{~mm}$ (approx. $3.5 \mathrm{~mm} /$ year). Figure 10 presents the remaining four points, where PS point no. 6 is located outside the influence of former mining operations (beyond former mining grounds) in the northern part of the city. The other three points located within boundaries of mining grounds show either three stages of movements (point no. 10) or two latter stages of movement (points nos. 11 and 12).

In general, all the points show upward movement of ground surface on the former mining grounds.

The magnitude of these movements ranges from 25 to $40 \mathrm{~mm}$ in the analysed period. The dynamics of the observed movements is differentiated depending on the part of the analysed area. In the Witold-Barbara former mining ground, which has been flooded the early 90'ties the graphs show three stages of movements that begin and end with stagnation (lack of significant movements). The PS points located in the northern part, flooded approx. at the same time as the Witold-Barbara zone, show upward movement throughout the 2002-2009 period. The displacements gradually decrease on selected points. The third area Victoria-Chrobry located in the centre shows characteristics of both areas bordering it in the south and in the north. Flooding of underground workings there occurred in the second part of the 90'ties. The probable factor responsible for the upward movement is associated with restoration of ground water table after the end mine water drainage and the reaction of the rock mass to this process. The differences in plot characteristics between the analysed points are due to different times of flooding particular coal fields. However, from these characteristics and the differences between the time of flooding (90'ties of $20^{\text {th }}$ Century) and registered upward surface movements ( $1^{\text {st }}$ decade of the $21^{\text {st }}$ Century) we assume that a delayed reaction of the rock mass to the rise in ground water table has been observed. In addition, the change in the direction of movement to subsidence is probably associated with the effect of shallow mining on the surface (deterioration of underground workings).

\section{CONCLUSIONS}

The presented study provides the first comprehensive results describing the characteristics of surface deformations in the former hard coal mining areas of Wałbrzych in the post-mining period (20022009). It has been obtained through processing of 

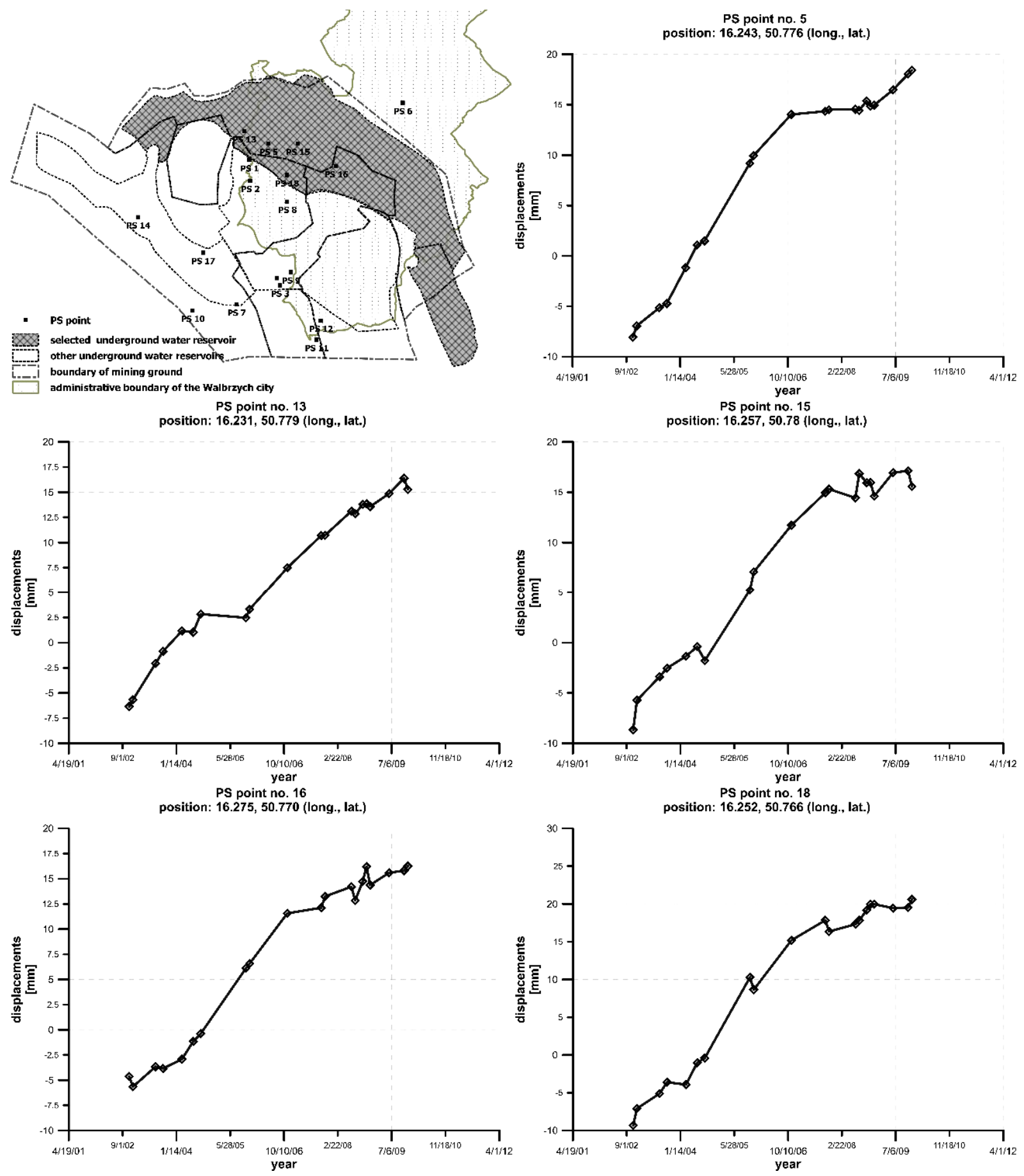

Fig. 7 Displacements (in Line of Sight) of selected representative PS in the Julia and Pokoj area in the 20022009 period.

satellite data with the PSInSAR methodology. This has allowed to present continuous surface displacements for the entire former mining site. During this time, the activity of surface movements within the boundaries of former mining grounds proceeded with varying intensity. The process was more dynamic in the initial years and diminished later. This was caused by the controlled and staged process of flooding successive coal fields of the Wałbrzych mines in the 90 'ties of the $20^{\text {th }}$ Century and the reaction of rock mass to restoration of groundwater table. Distinct zones of upward movement can be distinguished, associated with areas of late mining operations and subsequent flooding. The presented picture of surface movements is similar to other documented studies of rock mass activity in former mining areas in Europe (Cuenca et al., 2013; Samsonov et al., 2013). However, in the Walbrzych case study, the observed time difference between the rise in ground water table in the 90'ties and upward 

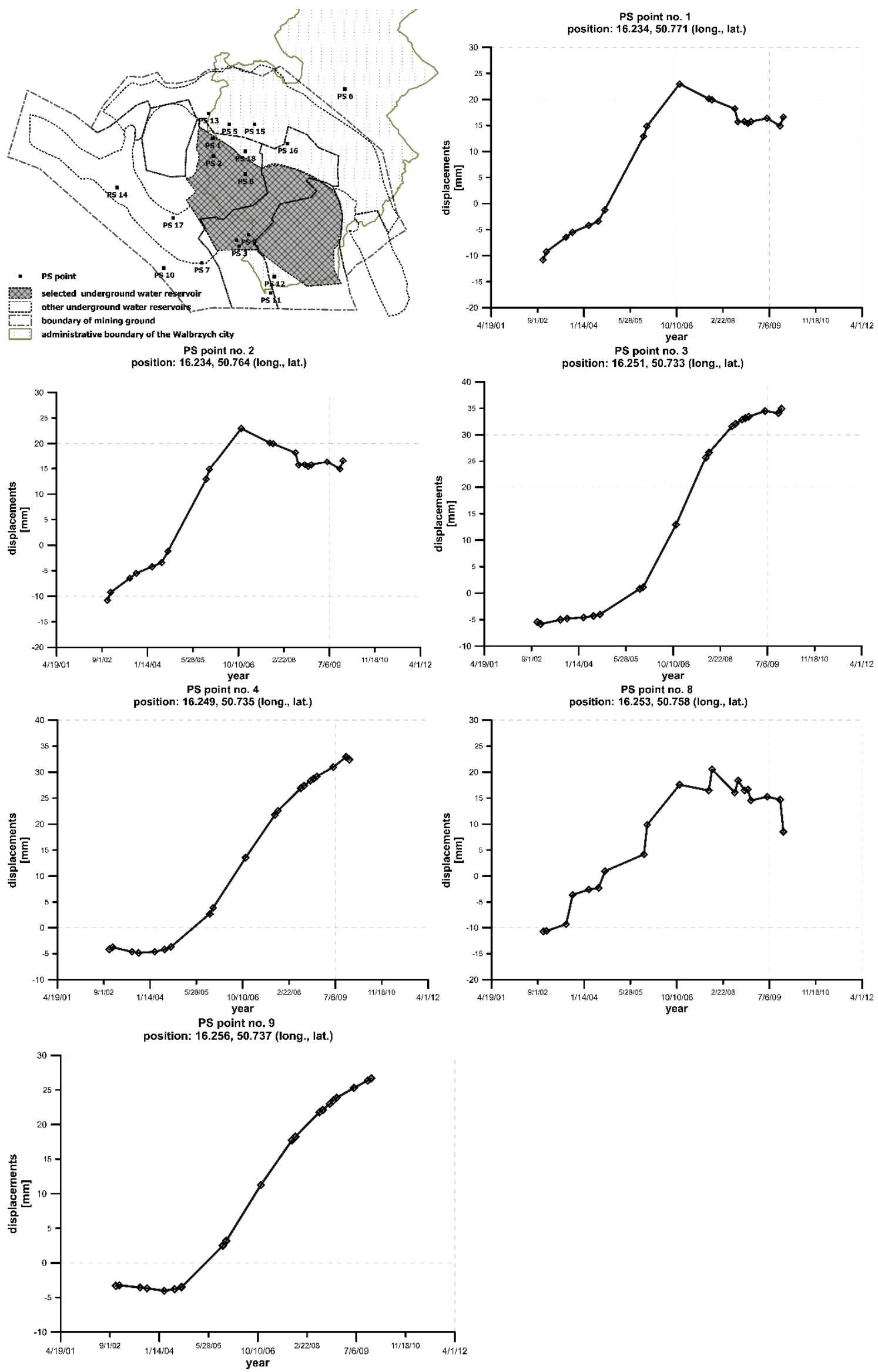

Fig. 8 Displacements (in Line of Sight) of selected representative PS in the Victoria-Chrobry area in the 20022009 period. 

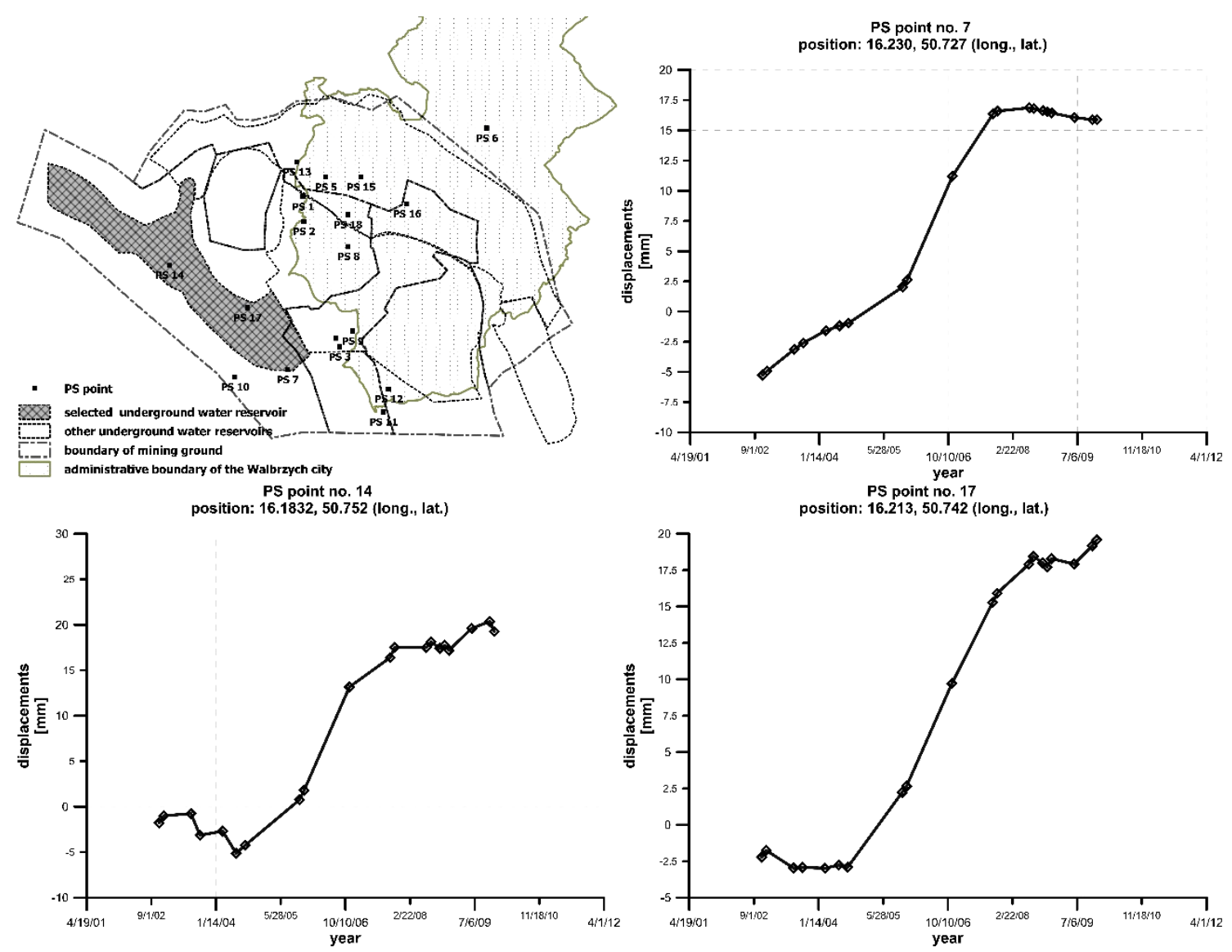

Fig. 9 Displacements (in Line of Sight) of selected representative PS in the Witold-Barbara area in the 20022009 period.
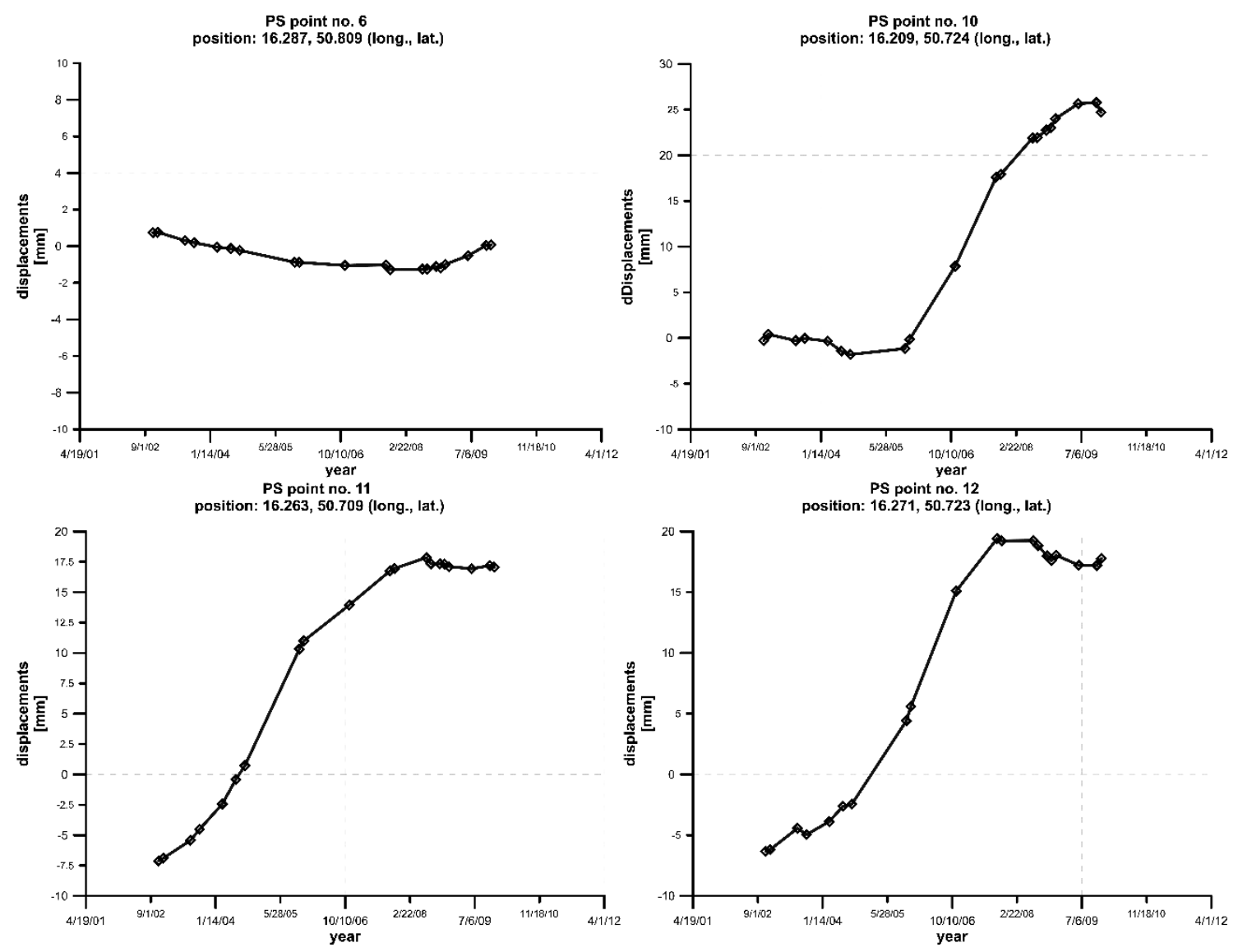

Fig. 10 Displacements (in Line of Sight) of selected representative PS nos. 6, 10, 11, 12 in the 2002-2009 period. Location of PS points has been shown in Figure 4. 
movement of ground surface registered in the first decade of the $21^{\text {st }}$ Century suggests a delayed reaction of the rock mass to change in ground water levels. With this study we aimed at bringing attention to the fact that the process of surface displacements in the Walbrzych area is still active even after the ground water table has been restored to its former levels. Further studies of surface movements aimed at precise correlation of hydrogeological data representing dynamics of coal fields flooding with PSInSAR results for the 90'ties are under way.

\section{ACKNOWLEDGMENTS}

This work has been realized in the National Science Centre Project „Development of a numerical method of mining ground deformation modelling in complex geological and mining conditions" UMO2012/07/B/ST10/04297, statutory grant no. 50068, and Project no. 18310 "Identification of rock mass surface deformations on abandoned mining areas" (the Envisat ASAR data are provided by European Space Agency) executed at the Faculty of Geoengineering, Mining and Geology of the Wroclaw University of Science and Technology (Poland).

\section{REFERENCES}

Bateson, L., Cigna, F., Boon, D. and Sowter, A.: 2015, The application of the Intermittent SBAS (ISBAS) InSAR method to the South Wales Coalfield, UK. International Journal of Applied Earth Observation and Geoinformation, 34, 249-257.

DOI: 10.1016/j.jag.2014.08.018

Blachowski, J.: 2008, Geographical information system of the Wałbrzych underground coal mines a way to improve effectiveness and accuracy of mining grounds deformation studies. Scientific Papers of the Institute of Mining Engineering. Wroclaw University of Technology, 123, 34, 17-27.

Blachowski, J., Milczarek, W. and Grzempowski, P.: 2015, Historical and present-day vertical movements on old mining terrains - case study of the Walbrzych coal basin (SW Poland). Acta Geodyn. Geomater., 12, No. 3, 227-23. DOI: 10.13168/AGG.2015.0020

Blachowski, J., Chrzanowski, A. and Szostak-Chrzanowski, A.: 2014, Application of GIS methods in assessing effects of mining activity on surface infrastructure. Archives of Mining Sciences, 59, 2, 307-321. DOI: $10.2478 / \mathrm{amsc}-2014-0022$

Blachowski, J., Milczarek, W. and Cacoń, S.: 2010, Project of a rock mass surface deformation monitoring system in the Walbrzych coal basin. Acta Geodyn. Geomater., 7, No. 3, 349-354.

Ciampalini, A., Bardi, F., Bianchini, S., Frodella, W., Del Ventisette, Ch., Moretti, S, and Casagli, N.: 2014, Analysis of building deformation in landslide area using multisensor PSInSAR ${ }^{\mathrm{TM}}$ technique. International Journal of Applied Earth Observation and Geoinformation, 33, 166-180. DOI: $10.1016 /$ j.jag.2014.05.011

Chaussard, E., Wdowinski, S., Cabral-Cano, E. and Amelung, F.: 2014, Land subsidence in central Mexico detected by ALOS InSAR time-series. Remote Sensing of Environment, 140, 94-106. DOI: $10.1016 /$ j.rse.2013.08.038
Cuenca, M.C., Hooper, A.J. and Hanssen, R.J.: 2012, Surface deformation induced by water influx in the abandoned coal mines in Limburg, the Netherlands observed by satellite radar interferometry. Journal of Applied Geophysics, 88, 1-11.

DOI: 10.1016/j.jappgeo.2012.10.003

Doležalová, H., Kajzar, V., Souček, K. and Staš, L.: 2009, Evaluation of mining subsidence using GPS data. Acta Geodyn. Geomater., 6, No. 3, 359-367.

Fenk, J.: 2000, Analytical solution describing upward movement of the surface during liquidation of underground mines through flooding. Przegląd Górniczy (Mining Review), 11, 12-14, (in Polish).

Ferretti, A., Savio, G., Barzaghi, R., Borghi, A., Musazzi, S., Novali, F., Prati, C. and Rocca, F.: 2007, Submillimeter accuracy of InSAR time series: Experimental validation. IEEE Transactions on Geoscience and Remote Sensing, 45, No. 5, 11421153. DOI: $10.1109 /$ TGRS.2007.894440

Ferretti, A., Prati, C. and Rocca, F.: 2001, Permanent scatterers in SAR interferometry. IEEE Transactions on Geoscience and Remote Sensing, 39, No. 1, 8-20. DOI: 10.1109/36.898661

Ferretti, A., Prati, C. and Rocca, F.: 2000, Nonlinear subsidence rate estimation using permanent scatterers in differential SAR interferometry. IEEE Transactions on Geoscience and Remote Sensing, 38, No. 5, 22022212. DOI: $10.1109 / 36.868878$

Fiszer, J., Koszela, J., Jerz, U., Muskała, M. and Pławecki, G.: 1998, Environmental Assessment of the Walbrzych Hard Coal Mines closure. Technical Report. Wrocław, (in Polish).

Fiszer, J. and Gogolewska, A.: 2003, Changes of groundwater conditions during the process of Lower Silesian Coal Basin closure. Wroclaw University of Technology. Institute of Mining Engineering Report No. 35, (in Polish).

Gourmelen, N., Amelung, F. and Lanari, R.: 2010, Interferometric synthetic aperture radar-GPS integration: Interseismic strain accumulation across the Hunter Mountain fault in the eastern California shear zone. J. Geophys. Res., 115, B9. DOI: 10.1029/2009JB007064

Jung, H.Ch., Kim, S.W., Jung, H.S., Min, K.D. and Won, J.S..: 2007, Satellite observation of coal mining subsidence by persistent scatterer analysis. Engineering Geology, 92, 1-13. DOI: $10.1016 /$ j.enggeo.2007.02.007

Hanssen, R.F.: 2001, Radar interferometry: Data interpretation and error analysis. Kluwer Academic Publishers, Dordrecht. DOI: 10.1007/0-306-47633-9

Hejmanowski, R., Malinowska, A., Stoch, T., Pluciñski, P., Warchala, M. and Kosior, R.: 2008, New interpretation of GPS measurements results. Mineral Resources Management, 23, 3, 197-204.

Herrera, G., Tomás, R., Lopez-Sanchez, J.M., Delgado, J., Mallorqui, J.J., Duque, S. and Mulas, J.: 2007, Advanced DInSAR analysis on mining areas: La Union case study (Murcia, SE Spain). Engineering Geology, 90, 148-159. DOI: 10.1016/j.enggeo.2007.01.001

Fan, H.D., Gu, W., Qin, Y., Xue, J.Q., Chen, B.Q.: 2014, A model for extracting large deformation mining subsidence using D-InSAR technique and probability integral method. Transactions of Nonferrous Metals Society of China, 24, 4, 1242-1247. DOI: $10.1016 / \mathrm{S} 1003-6326(14) 63185-\mathrm{X}$ 
Hooper, A., Zebker, H., Segall, P. and Kampes, B.: 2004, A new method for measuring deformation on volcanoes and other natural terrains using InSAR persistent scattrers. Geophys. Res. Lett., 31, L23611. DOI: 10.1029/2004GL021737

Hooper, A.: 2006, Persistent scatterer radar interferometry for crustal deformation studies and modeling of volcanic deformation. Ph.D. Thesis, Stanford University.

Hooper, A., Bekaert, D., Spaans, K. and Arıkan, H.: 2012, Recent advances in SAR interferometry time series analysis for measuring crustal deformation. Tectonophysics, 514, 1-13. DOI: $10.1016 /$ j.tecto.2011.10.013

Kampes, B., Hanssen, R. and Perski, Z.: 2003, Radar Interferometry with Public Domain Tools. In: Proceedings of FRINGE 2003, December 1-5, Frascati, Italy.

Kominowski, K.: 2000, Geology and hydrogeology. In: Kowalski, A. (Ed.), Mining and surface protection. Experiences from the Walbrzych mines. Central Mining Institute, Katowice, 33-48, (in Polish).

Kowalski, A. and Jędrzejec, E.: 2000. Threat to the surface caused by done mining and closure of mines. In: Kowalski, A. (Ed.), Mining and surface protection. Experiences from the Walbrzych mines. Central Mining Institute, Katowice, 343-366, (in Polish).

Kozuchowicz, S. and Oprychał, J.: 1984, Geological documentation of the Walbrzych Coal Mine hard coal deposit, (in Polish).

Kuşcu, S.: 1991. Mine subsidence monitoring and importance of subject in Zonguldak Coal Region in Turkey. Proceedings FIG International Symposium on Engineering Surveys, Sofia, Bulgaria, 225-236.

Lazecký, M. and Jiránková, E.: 2013, Optimization of satellite InSAR techniques for monitoring of subsidence in the surroundings of Karviná mine: Lazy plant. Acta Geodyn. Geomater., 10, No. 1, 51-55. DOI: $10.13168 /$ AGG.2013.0005

Jiang, L., Lin, H., Ma, J., Kong, B. and Wang, Y.: 2011, Potential of small-baseline SAR interferometry for monitoring land subsidence related to underground coal fires: Wuda (Northern China) case study. Remote Sensing of Environment, 115, 257-268. DOI: $10.1016 /$ j.rse. 2010.08 .008

Mathey, M.: 2013, Addressing the challenges involved with abandoned underground coal mines in South Africa. In: Proceedings of the 13th ISM Congress, Aachen, Germany, 113-123.

Milczarek, W.: 2014, Investigation, project and development of levelling network in the city of Walbrzych. Scientific Report of the Faculty of Geoengineering, Mining and Geology, Wroclaw University of Science and Technology, W06/2015/S21, (in Polish).

Muntean, A., Mocanu, V. and Ambrosius, B.: 2016. A GPS study of land subsidence in the Petrosani (Romania) coal mining area. Natural Hazards, 80, 2, 797-810. DOI: $10.1007 / \mathrm{s} 11069-015-1997-\mathrm{y}$
Peltier, A., Bianchi, M., Kaminski, E., Komorowski, J.-C., Rucci, A. and Staudacher, T.: 2010, PSInSAR as a new tool to monitor pre-eruptive volcano ground deformation: Validation using GPS measurements on Piton de la Fournaise. Geophys. Res. Lett., 37, L12301. DOI: 10.1029/2010GL043846

Perrone, G., Morelli, M., Piana, F., Fioraso, G., Nicolò ,G., Mallen, L., Cadoppi, P., Balestro, G. and Tallone, S.: 2013, Current tectonic activity and differential uplift along the Cottian Alps/Po Plain boundary (NW Italy) as derived by PS-InSAR data. Journal of Geodynamics, 66, 65-78.

DOI: $10.1016 /$ j.jog.2013.02.004

Raspini, F., Loupasakis, C., Rozos, D., Adam, N. and Moretti, S.: 2014, Ground subsidence phenomena in the Delta munici-pality region (Northern Greece): Geotechnical modeling and validation with Persistent Scatterer Interferometry. International Journal of Applied Earth Observation and Geoinformation, 28, 78-89. DOI: $10.1016 /$ j.jag.2013.11.010

Samsonov, S., d'Oreye, N. and Smets, B.: 2013, Ground deformation associated with post-mining activity at the French-German border revealed by novel InSAR time series method. International Journal of Applied Earth Observation and Geoinformation, 23, 142-154. DOI: $10.1016 /$ j.jag.2012.12.008

de Vent, I. and Roest, H.: 2013, Lagging mining damage in the Netherlands? Recent signs of soil movement in the Zuid-Limburg coal district. In: Proceedings of the 13th ISM Congress, Aachen, Germany, 27-41.

Zebker, H. A. and Goldstein, R. M.: 1986, Topographic mapping from interferometric synthetic aperture radar observations. J. Geophys. Res., 91, 4993-4999. DOI: 10.1029/JB091iB05p04993

Liu, Z.G., Bian, Z.F., Lei, S.G., Liu, D.L. and Sowter, A.: 2014, Evaluation of PS-DInSAR technology for subsidence monitoring caused by repeated mining in mountainous area. Transactions of Nonferrous Metals Society of China, 24, 3309-3315. DOI: $10.1016 / \mathrm{S} 1003-6326(14) 63471-3$

Zhang, Z., Wang, Ch., Tang, Y., Fu, Q. and Zhang, H.: 2015, Subsidence monitoring in coal area using timeseries InSAR combining persistent scatterers and distributed scatterers. International Journal of Applied Earth Observation and Geoinformation, 39, 49-55. DOI: 10.1016/j.jag.2015.02.007 

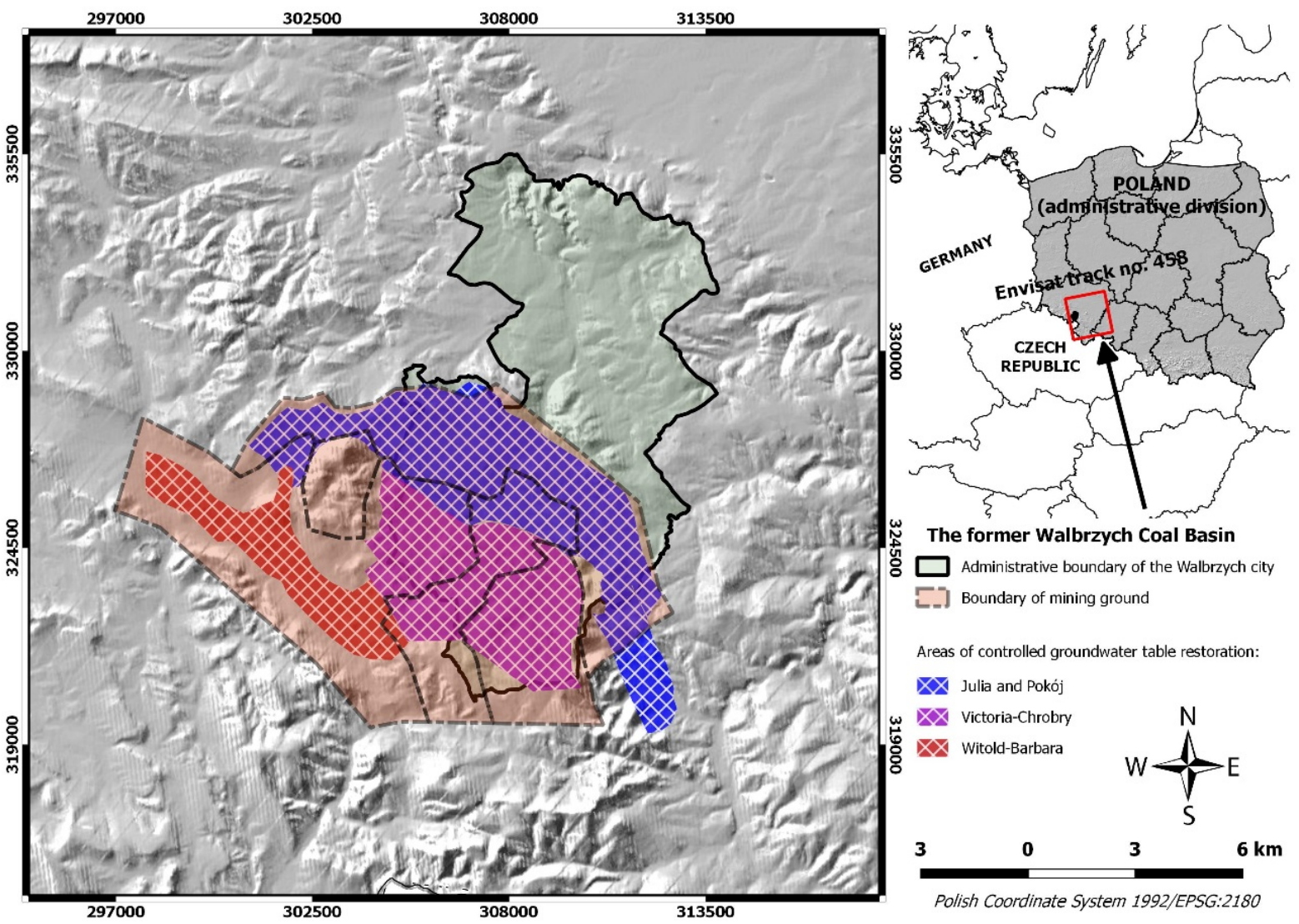

Fig. 1 Location of study area and boundaries of the former mining grounds in Wałbrzych.
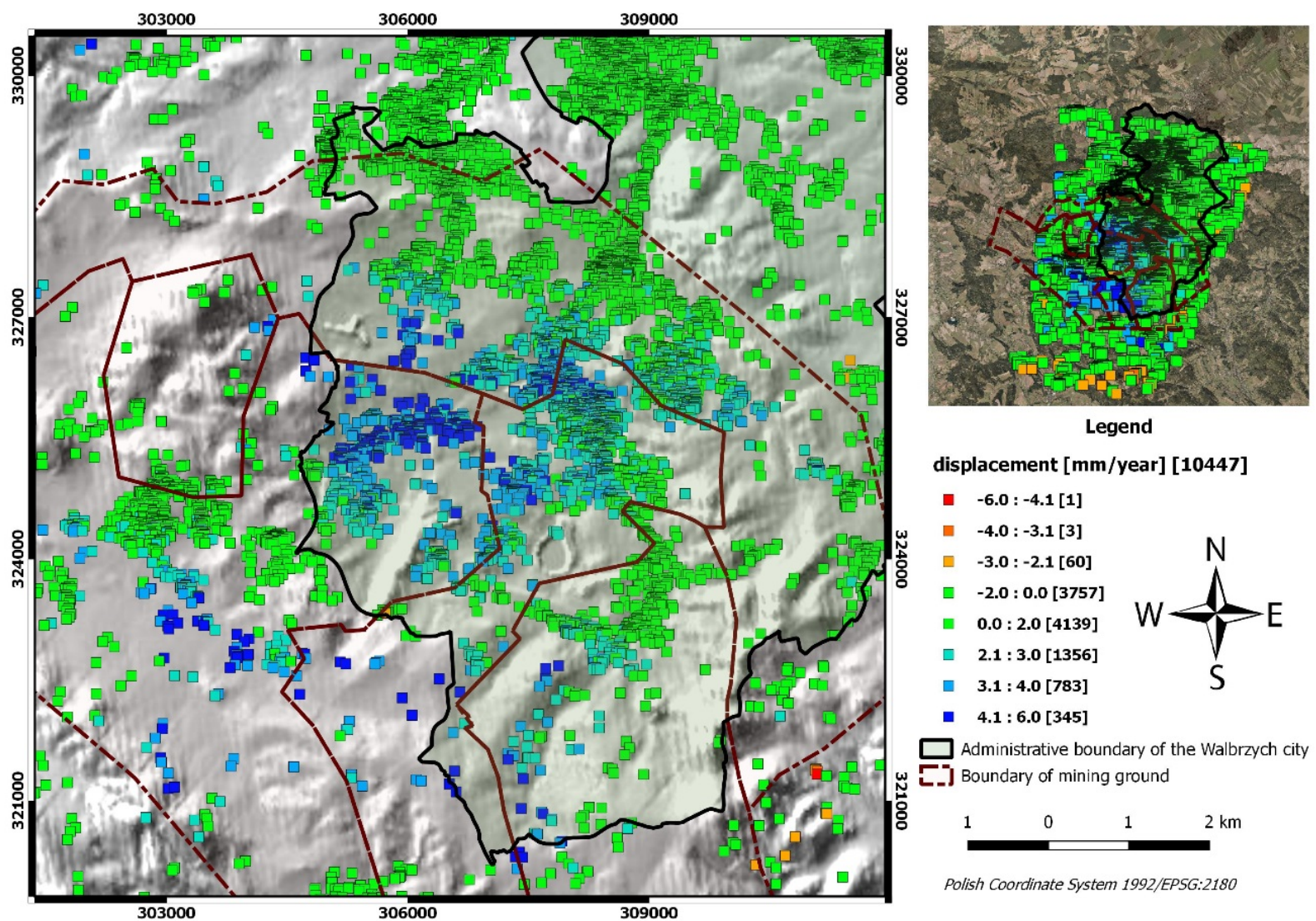

displacement [mm/year] [10447]

- $-6.0:-4.1[1]$

II $-4.0:-3.1[3]$

[- $-3.0:-2.1[60]$

ㅁ $-2.0: 0.0[3757]$

- $0.0: 2.0[4139]$

[ $2.1: 3.0[1356]$

- $3.1: 4.0[783]$

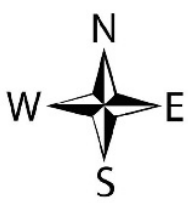

- $4.1: 6.0[345]$

$\square$ Administrative boundary of the Walbrzych city w.J Boundary of mining ground

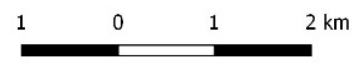

Polish Coordinate System 1992/EPSG:2180

Fig. 3 Spatial distribution of PS points and boundaries of former mining areas in Wałbrzych. 


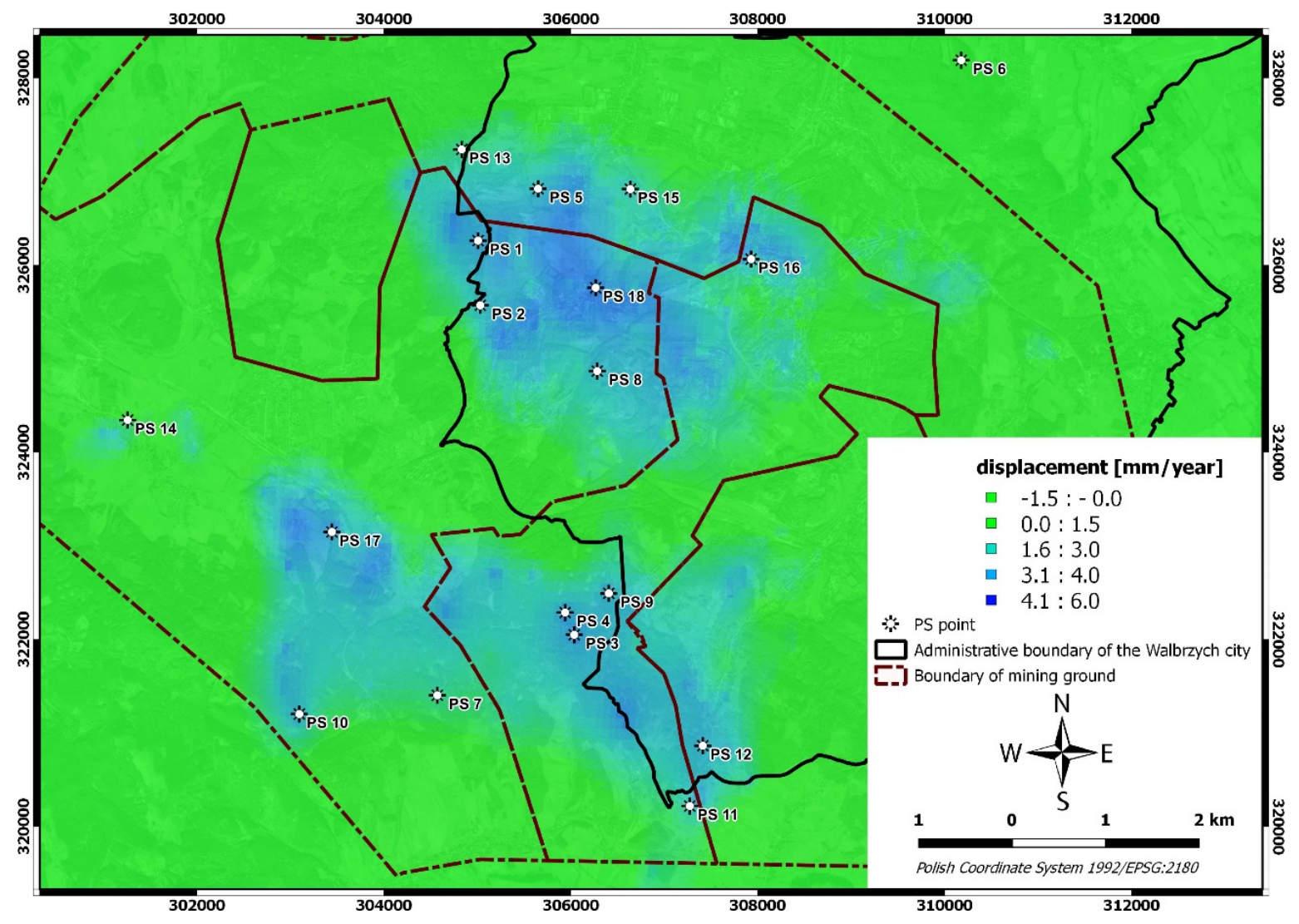

Fig. 4 Displacement surface on the former mining areas generated with the spline interpolation method in GIS from the PS points dataset.

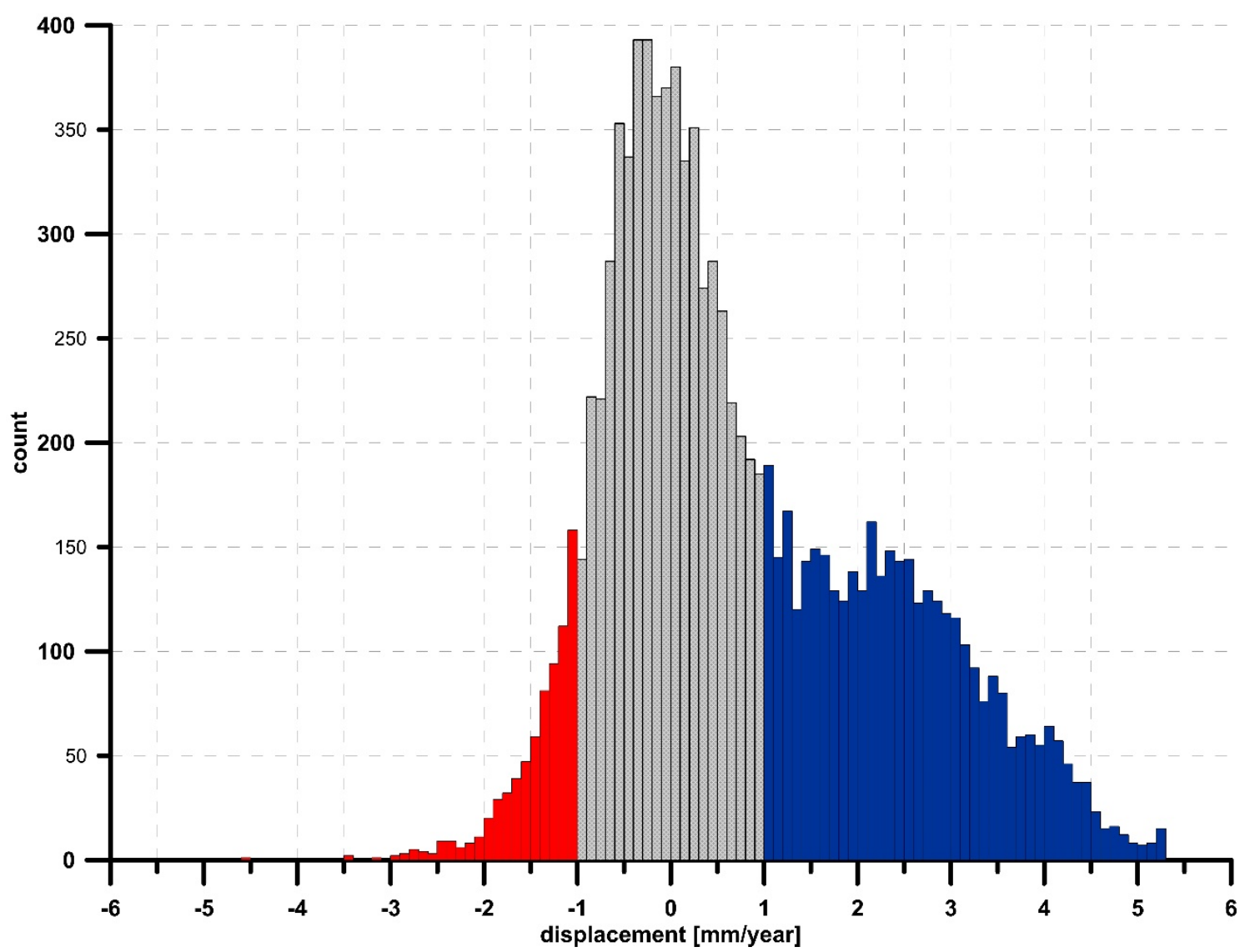

Fig. 5 Empirical distribution of average annual movements of PS points (in Line of Sight). Blue represents upward movement, red represents subsidence and grey represents points with movement values within the accuracy limits. 